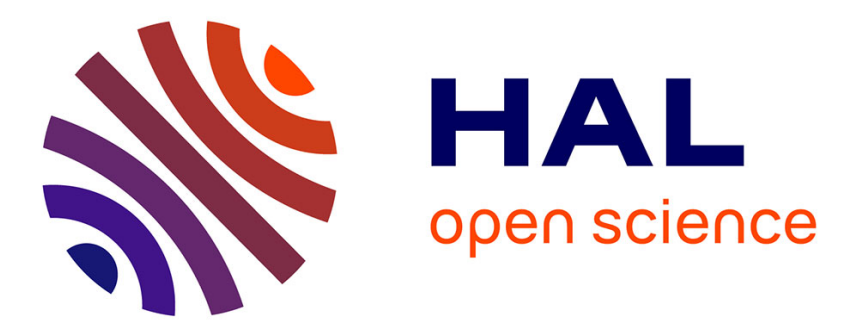

\title{
Estimation of tree biomass, carbon pool and net primary production of an old-growth Pinus kesiya Royle ex. Gordon forest in north-eastern India
}

\author{
Baishya, Saroj Barik
}

\section{To cite this version:}

Baishya, Saroj Barik. Estimation of tree biomass, carbon pool and net primary production of an old-growth Pinus kesiya Royle ex. Gordon forest in north-eastern India. Annals of Forest Science, 2011, 68 (4), pp.727-736. 10.1007/s13595-011-0089-8 . hal-00930822

\section{HAL Id: hal-00930822 \\ https://hal.science/hal-00930822}

Submitted on 1 Jan 2011

HAL is a multi-disciplinary open access archive for the deposit and dissemination of scientific research documents, whether they are published or not. The documents may come from teaching and research institutions in France or abroad, or from public or private research centers.
L'archive ouverte pluridisciplinaire $\mathbf{H A L}$, est destinée au dépôt et à la diffusion de documents scientifiques de niveau recherche, publiés ou non, émanant des établissements d'enseignement et de recherche français ou étrangers, des laboratoires publics ou privés. 


\title{
Estimation of tree biomass, carbon pool and net primary production of an old-growth Pinus kesiya Royle ex. Gordon forest in north-eastern India
}

\author{
Ratul Baishya $\cdot$ Saroj Kanta Barik
}

Received: 18 August 2010 / Accepted: 30 December 2010/Published online: 24 June 2011

(C) INRA and Springer Science+Business Media B.V. 2011

\begin{abstract}
- Background The data on carbon pool and biomass distribution pattern of old-growth Pinus kesiya Royle ex. Gordon forests are not available.

- Methods The forest carbon pool and annual net primary production (NPP) were assessed in three old-growth $P$. kesiya forest stands in north-eastern India, using biomass equations developed from 40 harvested trees between 9 and $63 \mathrm{~cm}$ in diameter at breast height (DBH) range.

- Results Regression models of the form $\log (\mathrm{Y})=\mathrm{a}+\mathrm{b}$ $\log \mathrm{D}+\mathrm{c}(\log \mathrm{D})^{2}+\mathrm{d}(\log \mathrm{D})^{3}$ were the best fits for biomass estimation of total tree and its various components. The total forest biomass (which includes live and dead compartments of trees, shrubs, and herbs) was $460.5 \mathrm{Mg} \mathrm{ha}^{-1}$, of which $91.2 \%$ was in the aboveground and $8.8 \%$ in the belowground compartment. P. kesiya contributed $77 \%$, broad-leaved tree species $13.5 \%$, shrubs $0.12 \%$, herbs $0.03 \%$ and litter $0.5 \%$ to the total forest biomass. The total ecosystem carbon content of the forest including soil organic carbon pool was 283.1 $\mathrm{Mg} \mathrm{C} \mathrm{ha}{ }^{-1}$. The annual net primary production (NPP) of the forest was $17.5 \mathrm{Mg} \mathrm{ha}^{-1} \mathrm{yr}^{-1}$.

- Conclusion The estimated total forest biomass and carbon pool of the $P$. kesiya forest were greater than for the other pine forests studied world-wide.
\end{abstract}

Handling Editor: Reinhart Ceulemans

R. Baishya

Department of Botany, University of Delhi,

Delhi 110007, India

S. K. Barik $(\bowtie)$

Centre for Advanced Studies in Botany, School of Life Sciences,

North-Eastern Hill University,

Shillong 793022 Meghalaya, India

e-mail: sarojkbarik@gmail.com
Keywords Old-growth Pinus kesiya forest - Tree biomass estimation models $\cdot$ Total forest carbon pool $\cdot$ Net primary production

\section{Introduction}

The carbon pool of a forest ecosystem varies with age (Clark et al. 2004; Kurz and Apps 1995). While young and middle-aged forest stands act as active carbon sinks (Valentini et al. 2000), old stands are moderate to small C sinks or even $\mathrm{C}$ sources, depending on the forest type and species composition (Desai et al. 2005; Knohl et al. 2003; Law et al. 2003; Malhi et al. 1999). However, most NPP studies world-wide have been carried out in relatively younger stands, and data on carbon content and NPP in oldgrowth pine forests are limited (Delrio et al. 2008).

Determination of carbon sequestration potential in terrestrial ecosystems through biomass estimation has been the most widely followed and appropriate approach (Brown 1997; Brown et al. 1989; Chambers et al. 2001). Regression models are used for biomass estimation because of their relative simplicity and ease for converting inventory data into a biomass estimate. Although it is difficult and tedious at the initial stage to develop the best-fit models, tree dimension values as the input data requirement for subsequent estimations have made the regression-based biomass estimation method extremely popular (Brown 1997). Several regression models have been developed to estimate biomass or biomass-related parameters (Brown et al. 1989; Schmidt et al. 2009), which are being used to prepare volume tables for several forestry species ( $\mathrm{Li}$ and Weiskittel 2010) and to estimate carbon in tropical, temperate, boreal, and semi-arid forest ecosystems (Schroeder et al. 1997). The total biomass data obtained 
from such models are then converted into carbon content for estimating carbon pools in different compartments, by multiplying by a conversion factor of 0.5 on the assumption that the tree biomass contains 50\% carbon (Ravindranath et al. 1997; Richter et al. 1995).

Although several workers have used tree height, trunk diameter [i.e., diameter at breast height (DBH)] and wood density as independent variables for estimating tree aboveground biomass (AGB), the allometric relationship between AGB and DBH has been proved to be the best fit for tree biomass estimation in several forests (Brown 1997; Brown et al. 1989). The carbon present in other compartments of the ecosystem such as shrub, herb, litter, woody debris, root, and soil is added to the tree carbon data to obtain the size of the total carbon pool in a forest ecosystem. Since AGB of trees contains a large fraction of the total forest carbon stock, most studies on forest carbon budget have focused only on tree AGB estimation. Although these studies do provide empirical data on the major carbon pool of the forest, total ecosystem level carbon data for most ecosystems is lacking.

Net primary productivity (NPP), the balance between the light energy fixed through photosynthesis and respiratory loss and mortality, represents the net carbon input from the atmosphere to terrestrial vegetation (Melillo et al. 1993). It is the net organic matter produced by live plants at the end of a specific time interval (Clark et al. 2001). It is an important index for estimating carbon budget and evaluating the patterns, processes and dynamics of carbon cycling in forest ecosystems at local, regional and global scales (Luo et al. 2002). Most studies on NPP estimation consider only the increment in AGB and litterfall, and completely ignore the belowground component. Cairns et al. (1997) argued that the approach of allometric modeling should be more realistic than root/shoot ratio for estimating tree belowground biomass (BGB). For estimating ecosystem level NPP of a forest, timeseries biomass data for tree, shrub, herb, and litter components are pre-requisites. However, such data for different components other than tree are not available easily, and therefore studies on total ecosystem level NPP estimation are limited.

The natural forests of Pinus kesiya Royle ex. Gordon are found throughout north-eastern India at an elevation range of 800-2,000 ma.s.l., and extend up to the Philippines through Myanmar and Vietnam (Changala and Gibson 1984). Plantation forests of the species have been reported from such far-off places as Kenya, Zimbabwe, and Tanzania, indicating its global importance. P. kesiya has been invading the montane subtropical broad-leaved forest areas of north-eastern India once the primary broad-leaved forest species are cleared (Barik et al. 1996). Therefore, $P$. kesiya forest is very important for north-eastern India as a carbon sink. Although the AGB and NPP of a P. kesiya plantation forest were studied by Das and Ramakrishnan (1987) along an age series of 1-22 years through developing an allometric model, the model did not fit well to the old-growth forests. As such, the total as well as compartment-wise carbon pool, and NPP of natural oldgrowth $P$. kesiya forests have not been studied. Therefore, the present study was undertaken (i) to develop regression models for biomass estimation of Pinus kesiya and broadleaved trees, and (ii) to estimate carbon pools in different compartments, and (iii) net primary productivity of an oldgrowth Pinus kesiya forest ecosystem.

\section{Materials and methods}

\subsection{Study site and climate}

The study was conducted in Riat Laban reserved forest (latitude $25^{\circ} 55^{\prime} \mathrm{N}$, longitude $91^{\circ} 88^{\prime} \mathrm{E}$, elevation $1,643 \mathrm{~m}$ a.s.l, area 2.0 sq. km), and its adjoining Laitkor (latitude $25^{\circ} 56^{\prime} \mathrm{N}$, longitude $91^{\circ} 89^{\prime} \mathrm{E}$, elevation 1,660 ma.s.l., area $3.2 \mathrm{sq} . \mathrm{km}$ ) and Upper Shillong (latitude $25^{\circ} 56^{\prime} \mathrm{N}$, longitude $91^{\circ} 85^{\prime} \mathrm{E}$, elevation 1,655 ma.s.1., area 7.9 sq. km) community forests in Meghalaya during 2005-2007. The forest stands are natural, continuous, well-protected, 65-80 years old and are dominated by Pinus kesiya. The forest is classified as Assam sub-tropical pine forest (Champion and Seth 1968). The study site received an average annual rainfall of $2466.2 \mathrm{~mm}$ during the study period. The average monthly temperature varied from a maximum of $22.9^{\circ} \mathrm{C}$ in the month of July to a minimum of $1.8^{\circ} \mathrm{C}$ in December.

The density of $P$. kesiya contributed to $71-73 \%$ of the total tree density in the forest. Lyonia ovalifolia Hort., with density ranging between 6 and 159 trees $\mathrm{ha}^{-1}$, was the dominant sub-canopy tree species in all the three stands. The other associated tree species were Alnus nepalensis D. Don, Lithocarpus dealbatus Rehder, Lyonia ovalifolia Hort., Myrica esculenta Buch.-Ham. ex D. Don, Rhododendron arboretum Sm., and Schima wallichii Choisy. The shrub layer was dominated by Eupatorium adenophorum Spreng and Lantana camara L. Some of the herbaceous species were Arundinella benghalensis Druce, Duchesnea indica Focke, Eupatorium riparium Regel, Gnaphalium luteoalbum L., Imperata cylindrica Beauv., Paspalam dilatatum Poir, Plantago major L., Pouzolzia hirta Hassk, Potentilla fulgens Wall. ex Hook., and Rananculus scleratoides Perf. ex Ovczinn. Aeginetia indica L. was the dominant herb on decomposing litter. Smilax aspera DC. and S. ovalifolia A. DC. were the dominant climbers in the forest.

\subsection{Determination of forest age and analysis of tree} population structure

Six permanent plots of $250 \mathrm{~m} \times 20 \mathrm{~m}$ size were laid in the three stands. In each plot, all trees with $\geq 5 \mathrm{~cm}$ DBH were 
tagged, measured, and identified. The girth of each individual tree was measured. The tree species other than $P$. kesiya were identified with the help of regional flora (Haridasan and Rao 1985-1987). The ASSAM herbarium at Botanical Survey of India, Shillong was consulted for confirmation. The density and basal area were calculated following Misra (1968). For depicting tree population structure of the forest, all trees including broad-leaved species were grouped into eight diameter classes i.e.: >5-9.9, 10-19.9, 20-29.9, 30-39.9, 40-49.9, $50-59.9,60-69.9$ and $70-79.9 \mathrm{~cm}$. The diameter-density distribution of $P$. kesiya was presented.

\subsection{Estimation of total biomass and carbon of the forest}

The total forest biomass was estimated by adding the biomass of the following components: (i) P. kesiya trees, (ii) broadleaved trees, (iii) litter, and (iv) shrubs and herbs. Since biomass models for $P$. kesiya, particularly in old-growth forests, were not available, allometric biomass equations were developed for AGB and BGB estimation. The existing biomass models for broad-leaved species (Cairns et al. 1997; Chambers et al. 2001) were used to estimate the BGB and AGB of broad-leaved trees in the forest. The biomass of shrubs and herbs were directly estimated through a harvest method following Misra (1968). The mean biomass values calculated from the six permanent plots in the three sites were presented. Carbon content of each component was calculated as $50 \%$ of the ash-free mass. Ash content was determined by igniting the oven-dried plant materials at $550^{\circ} \mathrm{C}$ for 6 hours in a muffle furnace.

\subsection{Estimation of P. kesiya tree biomass for model development}

Forty trees of $P$. kesiya were randomly selected for felling from the three forest stands. The trees selected for the Riat Laban reserved forest stand were from the adjacent community forest area, which is continuous with the reserve, since felling of tree is banned inside the reserve. The trees selected in the two community forest stands were from the peripheral areas of the stands. Five to six trees were selected from each of the seven diameter classes of $P$. kesiya i.e.: >5-9.9, 10-19.9, 20-29.9, 30-39.9, 40-49.9, 50-59.9 and 60-69.9 cm, which represented the minimum and maximum diameter range of the species in the forest. The DBH of the felled trees was measured. The age of the pine forest was determined by counting the annual growth rings in circular sections taken from the above mentioned 40 sample trees. The counting of the rings was done in sections taken at $30 \mathrm{~cm}$ from the base of the tree. The mean value represented the age of the forest stand. The trees were separated into stem, branch, twig, needle, reproductive part, and root components, and the fresh weight of each component was taken. Three replicate samples of $2 \mathrm{~kg}$ each for each component were oven-dried at $80^{\circ} \mathrm{C}$ till constant weight was achieved. For estimation of BGB, the roots of each cut tree were excavated as completely as possible, and separated into fine roots $(<2 \mathrm{~mm}$ diameter $)$ and coarse roots $(>2 \mathrm{~mm}$ diameter). Both the coarse and fine roots of each cut tree were weighed in the field. The portion of the tree stump that remains underground was treated as a part of the coarse root. The root samples in triplicate were brought to the laboratory and oven-dried at $80^{\circ} \mathrm{C}$ till constant weight was achieved.

\subsection{Development and evaluation of allometric models}

Regression models were developed considering tree DBH as independent variable, and stem, branch, twig, needle, reproductive part, root, total aboveground, and total tree biomass as dependent variables. The DBH and dry weight values were log-transformed, and nonlinear regression models were fitted for different tree components, as well as for total tree biomass. For selecting the best-fit models, the coefficient of determination $\left(\mathrm{R}^{2}\right)$, standard deviation (SD), sum of square error (SSE), mean square error (MSE) and root mean square error (RMSE) of the allometric equations were compared with those of existing models developed by earlier workers (Brown 1997; Delrio et al. 2008; Ter-Mikaelian and Korzukhin 1997) for Pinus spp.

The models developed by Chambers et al. (2001) for AGB and Cairns et al. (1997) for BGB estimation were used for determining broad-leaved tree biomass. The allometric model for the aboveground component $\left(\mathrm{Y}_{1}\right)$ is: $\ln \left(\mathrm{Y}_{1}\right)=-0.37+$ $0.333 \ln \mathrm{D}+0.933[\ln (\mathrm{D})]^{2}-0.122[\ln (\mathrm{D})]^{3}$, and that for belowground component $\left(\mathrm{Y}_{2}\right)$ is: $\mathrm{Y}_{2}=\operatorname{Exp}[-1.085+0.9256$ $(\ln \mathrm{AGB})]$. These two models were selected based on $\mathrm{R}^{2}, \mathrm{SD}$, SSE, MSE, and RMSE values.

\subsection{Litter}

Litterfall was estimated at monthly interval over a period of 2 years from September, 2005 to August, 2007. Five traps of $1 \mathrm{~m} \times 1 \mathrm{~m} \times 0.15 \mathrm{~m}$ (length $\times$ breadth $\times$ height $)$ were placed within each permanent plot $(n=120)$. The litter components were segregated into five fractions, viz., leaf, twig, branch, cone, and reproductive parts. The biomass of each component was determined after oven-drying the samples at $80^{\circ} \mathrm{C}$ till constant weight was achieved.

\subsection{Analysis of soil organic carbon}

Composite soil samples were collected from each of the six permanent plots up to $1 \mathrm{~m}$ depth from the surface. Soil samples were collected during each of the four seasons of 
the year 2005, and analysis for determination of soil organic carbon content was done after air-drying and sieving the soil samples through a $2-\mathrm{mm}$ mesh sieve. Soil organic carbon was estimated following the colorimetric method described by Anderson and Ingram (1993).

\subsection{Estimation of NPP}

The NPP of the forest was determined from the NPP estimates for each component, i.e., tree, shrub, herb, and litter in the six permanent sample plots. The NPP was estimated for all these components for 2 consecutive years (i.e., 2006 and 2007), and the mean values were presented. The biomass for $P$. kesiya was estimated by applying the allometric equations developed in this study, and for other broad-leaved tree species it was estimated using the equations of Chambers et al. (2001) for AGB and Cairns et al. (1997) for BGB. The standing tree biomass component of NPP was estimated by subtracting biomass estimated for September 2005 from that of August 2006, and biomass for September 2006 from that of August 2007, for the years 2006 and 2007 respectively. The aboveground NPP was determined by summing the tree biomass component of NPP and annual litter production measured at the same time interval (Kira and Shidei 1967). The annual root production was measured by sampling roots using a soil augur in four seasons each year. The roots were washed and segregated into fine and coarse roots, and the biomass was determined for each component after ovendrying the samples in $80^{\circ} \mathrm{C}$ till constant weight was achieved. The annual root production was measured by summing up the positive increments in live root biomass and concurrent positive increment in the dead root biomass during the successive samplings (Persson 1978). The NPP for shrubs and herbs was estimated using the biomass data for the same time interval as standing tree biomass component.

\section{Results}

\subsection{Allometric biomass models for P. kesiya}

The aboveground biomass data for 40 trees (Table 1) were regressed against the DBH using the regression models developed by the earlier workers for pine species. None of these models yielded a satisfactory coefficient of determination $\left(\mathrm{R}^{2}\right)$, MSE and RMSE. Hence, the following form of model was developed by log transforming the data of each tree component, which yielded greater $\mathrm{R}^{2}$ and lower MSE, SSE and RMSE than the earlier models -

$\log (Y)=a+b \log D+c(\log D)^{2}+d(\log D)^{3}$ where $\mathrm{Y}=\mathrm{AGB}(\mathrm{kg} /$ tree $), \mathrm{a}, \mathrm{b}, \mathrm{c}$, and $\mathrm{d}$ are regression coefficients, and $\mathrm{D}$ is the stem diameter at breast height. All the measures of coefficients of the models for tree components were statistically significant $(P<0.001)$ (Fig. 1).

\subsection{Density of trees, shrubs and herbs}

The density of trees in the forest ranged between 628 and 947 trees $\mathrm{ha}^{-1}$. The density of $P$. kesiya ranged between 454 and 677 trees $\mathrm{ha}^{-1}$. The total tree basal areas of the three forest stands were 70.6, 66 and $126 \mathrm{~m}^{2} \mathrm{ha}^{-1}$ respectively. P. kesiya contributed to $97.4,96.5$ and $74 \%$ of the total basal area in the three stands. The total shrub density of the forest was 4,400 plants ha ${ }^{-1}$, and that for herb was 385,000 plants ha ${ }^{-1}$.

\subsection{Estimation of total forest biomass and NPP}

The total biomass of the forest was $460.5 \mathrm{Mg} \mathrm{ha}^{-1}$, of which $91.2 \%$ was in the aboveground compartment and $8.8 \%$ in the belowground compartment. P. kesiya contributed $77 \%$, broad-leaved tree species $13.5 \%$, shrubs $0.12 \%$, herbs $0.03 \%$ and litter $0.5 \%$ to the total forest biomass (Table 2). The total AGB of pine including litter, herb and shrub components was $357.6 \mathrm{Mg} \mathrm{ha}^{-1}$. The tree AGB and BGB were 419.7 and $40.8 \mathrm{Mg} \mathrm{ha}^{-1}$ respectively. While $P$. kesiya had $354.6 \mathrm{Mg} \mathrm{ha}^{-1}$ as AGB and $31.8 \mathrm{Mg} \mathrm{ha}^{-1}$ as BGB, the corresponding figures for the broad-leaved species were only 62.2 and $9.0 \mathrm{Mg} \mathrm{ha}^{-1}$ respectively (Table 2). The needles, twigs, branches, and reproductive parts accounted for 44.9, $31.3,4.8$, and $18.9 \%$ respectively to the total litterfall. The fine and coarse root biomass of $P$. kesiya were 0.5 and $6.4 \%$ of the total forest biomass and constituted $6 \%$ and $72 \%$ of the total BGB, respectively. The BGB of broad-leaved species was only $1.9 \%$ of the total forest ecosystem biomass and $22 \%$ of the total BGB. The total ecosystem NPP of the forest was $17.5 \mathrm{Mg} \mathrm{ha}^{-1} \mathrm{yr}^{-1}$. The leaf litter, twig, branch, and reproductive parts contributed to $42.6,14.9,10.6$, and $31.9 \%$ of the total litter production. The stem $(55 \%)$, branches (8.6\%), and twigs, needles, and reproductive parts (8.6\%) of P. kesiya were the major contributors to the total ecosystem NPP. The total ecosystem carbon content of the forest was $283.1 \mathrm{Mg} \mathrm{C} \mathrm{ha}^{-1}$ (Table 2). The soil organic carbon was $58.7 \mathrm{Mg} \mathrm{ha}^{-1}$, contributing $20.7 \%$ to the total ecosystem carbon. The DBH class $50-59.9 \mathrm{~cm}$ had the highest tree density among all the DBH classes, and hence contributed maximum biomass of $115.9 \mathrm{Mg} \mathrm{ha}^{-1}$, which accounted for $27.8 \%$ of the total AGB of the forest (Fig. 2).

\section{Discussion}

In most allometric models that relate biomass with $\mathrm{DBH}$, the variability in untransformed data increases with increase 
Table 1 Dry weight (kg) of different components of Pinus kesiya tree used for developing regression models

\begin{tabular}{|c|c|c|c|c|c|c|c|c|c|c|}
\hline $\mathrm{DBH}(\mathrm{cm})$ & Stem & Branch & Twig & Needle & Cone & Fine root & Coarse root & Total root & Total AGB & Total tree \\
\hline 9.01 & 15.18 & 4.99 & 3.27 & 1.53 & 0.42 & 0.31 & 2.22 & 2.53 & 25.38 & 27.90 \\
\hline 9.20 & 15.57 & 6.28 & 3.83 & 1.97 & 0.44 & 0.98 & 2.54 & 3.52 & 28.08 & 31.60 \\
\hline 11.28 & 19.61 & 8.13 & 3.96 & 1.88 & 0.90 & 0.26 & 3.18 & 3.44 & 34.46 & 37.90 \\
\hline 11.41 & 20.12 & 8.51 & 3.40 & 2.00 & 0.97 & 0.29 & 3.61 & 3.90 & 35.01 & 38.91 \\
\hline 12.37 & 22.19 & 9.72 & 3.53 & 2.13 & 0.82 & 0.55 & 6.76 & 7.31 & 38.38 & 45.69 \\
\hline 13.94 & 32.51 & 12.99 & 3.27 & 4.97 & 2.22 & 0.95 & 11.65 & 12.61 & 55.96 & 68.56 \\
\hline 14.33 & 48.25 & 14.02 & 3.40 & 4.66 & 2.38 & 1.05 & 12.81 & 13.85 & 72.70 & 86.55 \\
\hline 15.96 & 41.11 & 19.61 & 4.56 & 5.49 & 2.33 & 1.43 & 17.50 & 18.93 & 73.09 & 92.02 \\
\hline 16.12 & 63.08 & 23.91 & 5.42 & 4.76 & 2.60 & 1.46 & 17.94 & 19.41 & 99.76 & 119.17 \\
\hline 17.12 & 81.36 & 28.34 & 6.71 & 5.34 & 2.51 & 1.68 & 20.62 & 22.31 & 124.24 & 146.55 \\
\hline 18.11 & 88.84 & 35.52 & 8.15 & 5.01 & 3.25 & 1.89 & 23.19 & 25.08 & 140.77 & 165.85 \\
\hline 19.29 & 72.93 & 22.49 & 9.72 & 6.67 & 2.58 & 2.13 & 26.10 & 28.23 & 114.39 & 142.62 \\
\hline 22.60 & 121.52 & 37.20 & 8.28 & 5.40 & 3.27 & 2.73 & 33.40 & 36.13 & 175.67 & 211.80 \\
\hline 23.15 & 133.86 & 48.29 & 9.61 & 6.12 & 3.07 & 2.82 & 34.52 & 37.33 & 200.94 & 238.28 \\
\hline 27.76 & 287.37 & 83.95 & 10.99 & 6.48 & 2.66 & 3.47 & 42.60 & 46.08 & 391.44 & 437.52 \\
\hline 28.59 & 287.37 & 83.91 & 10.99 & 6.48 & 3.37 & 3.58 & 43.85 & 47.43 & 392.12 & 439.55 \\
\hline 32.76 & 354.54 & 86.06 & 11.72 & 6.41 & 3.27 & 4.01 & 49.22 & 53.23 & 462.01 & 515.24 \\
\hline 35.03 & 376.52 & 80.57 & 11.52 & 6.22 & 5.83 & 4.20 & 51.56 & 55.76 & 480.66 & 536.42 \\
\hline 37.12 & 425.53 & 82.26 & 11.87 & 6.55 & 7.20 & 4.35 & 53.38 & 57.73 & 533.40 & 591.13 \\
\hline 38.11 & 478.43 & 84.99 & 11.33 & 7.29 & 4.77 & 4.41 & 54.14 & 58.55 & 586.80 & 645.35 \\
\hline 39.29 & 502.51 & 90.58 & 14.06 & 8.15 & 5.16 & 4.48 & 54.96 & 59.44 & 620.46 & 679.89 \\
\hline 40.61 & 578.48 & 88.92 & 14.02 & 7.38 & 3.95 & 4.54 & 55.77 & 60.31 & 692.75 & 753.07 \\
\hline 43.47 & 640.42 & 93.03 & 13.91 & 7.52 & 4.65 & 4.66 & 57.19 & 61.84 & 759.54 & 821.39 \\
\hline 47.53 & 722.25 & 105.93 & 15.20 & 8.38 & 9.88 & 4.76 & 58.48 & 63.24 & 861.65 & 924.89 \\
\hline 48.27 & 730.40 & 101.70 & 15.57 & 7.09 & 5.15 & 4.77 & 58.63 & 63.40 & 859.90 & 923.30 \\
\hline 49.23 & 739.84 & 106.12 & 14.04 & 8.16 & 8.38 & 4.78 & 58.80 & 63.58 & 876.53 & 940.11 \\
\hline 49.74 & 750.93 & 102.00 & 13.14 & 7.92 & 6.39 & 4.79 & 58.87 & 63.66 & 880.38 & 944.04 \\
\hline 51.41 & 769.36 & 110.38 & 15.70 & 8.43 & 4.18 & 4.80 & 59.05 & 63.86 & 908.04 & 971.89 \\
\hline 52.95 & 799.52 & 114.25 & 15.10 & 8.37 & 6.39 & 4.81 & 59.14 & 63.94 & 943.63 & $1,007.57$ \\
\hline 53.59 & 815.11 & 105.93 & 17.01 & 9.12 & 7.13 & 4.81 & 59.15 & 63.96 & 954.31 & $1,018.27$ \\
\hline 54.58 & 836.39 & 124.40 & 16.94 & 7.57 & 7.88 & 4.81 & 59.15 & 63.95 & 993.18 & $1,057.14$ \\
\hline 56.70 & 961.72 & 115.52 & 13.81 & 7.71 & 5.62 & 4.80 & 59.06 & 63.86 & $1,104.37$ & $1,168.23$ \\
\hline 57.44 & $1,000.33$ & 114.43 & 15.63 & 8.46 & 6.65 & 4.79 & 59.01 & 63.81 & $1,145.50$ & $1,209.31$ \\
\hline 59.49 & $1,046.02$ & 93.03 & 14.04 & 8.16 & 8.77 & 4.78 & 58.82 & 63.59 & $1,170.02$ & $1,233.61$ \\
\hline 59.90 & $1,056.21$ & 101.31 & 13.14 & 8.38 & 9.88 & 4.77 & 58.77 & 63.54 & $1,188.93$ & $1,252.47$ \\
\hline 60.10 & $1,080.29$ & 105.93 & 15.70 & 7.09 & 5.15 & 4.77 & 58.75 & 63.52 & $1,214.16$ & $1,277.68$ \\
\hline 61.28 & $1,085.15$ & 101.70 & 15.10 & 8.16 & 8.38 & 4.76 & 58.60 & 63.36 & $1,218.48$ & $1,281.84$ \\
\hline 61.28 & $1,104.67$ & 106.12 & 17.01 & 7.92 & 6.39 & 4.76 & 58.60 & 63.36 & $1,242.10$ & $1,305.45$ \\
\hline 62.37 & $1,142.38$ & 102.00 & 16.94 & 8.43 & 4.18 & 4.74 & 58.45 & 63.20 & $1,273.93$ & $1,337.13$ \\
\hline 62.69 & $1,184.05$ & 110.38 & 13.81 & 8.37 & 6.39 & 4.74 & 58.41 & 63.15 & $1,323.00$ & $1,386.14$ \\
\hline
\end{tabular}

in diameter (Beauchamp and Olson 1973). The log transformation brings the variance down to uniformity by stretching the smaller values and compressing the larger values. The actual biomass values are obtained from the model-derived values through antilog transformation (Ovington and Olson 1970). The log-transformed DBH data of the harvested trees used for the model development yielded lower variance (0.074), standard deviation (0.272) and standard error $(0.043)$ than the untransformed DBH. The variance $(0.056-0.076)$, standard deviation $(0.238-$ $0.275)$ and standard error $(0.008-0.009)$ of the logtransformed DBH data in the three pine forest stands, used for estimating total forest biomass, were also low. Several authors (Baskerville 1972; Beauchamp and Olson 1973) 
Fig. 1 Regression analyses between tree diameter at breast height $(\mathrm{cm})$, and biomass of different tree components, above ground biomass and total tree biomass of Pinus kesiya
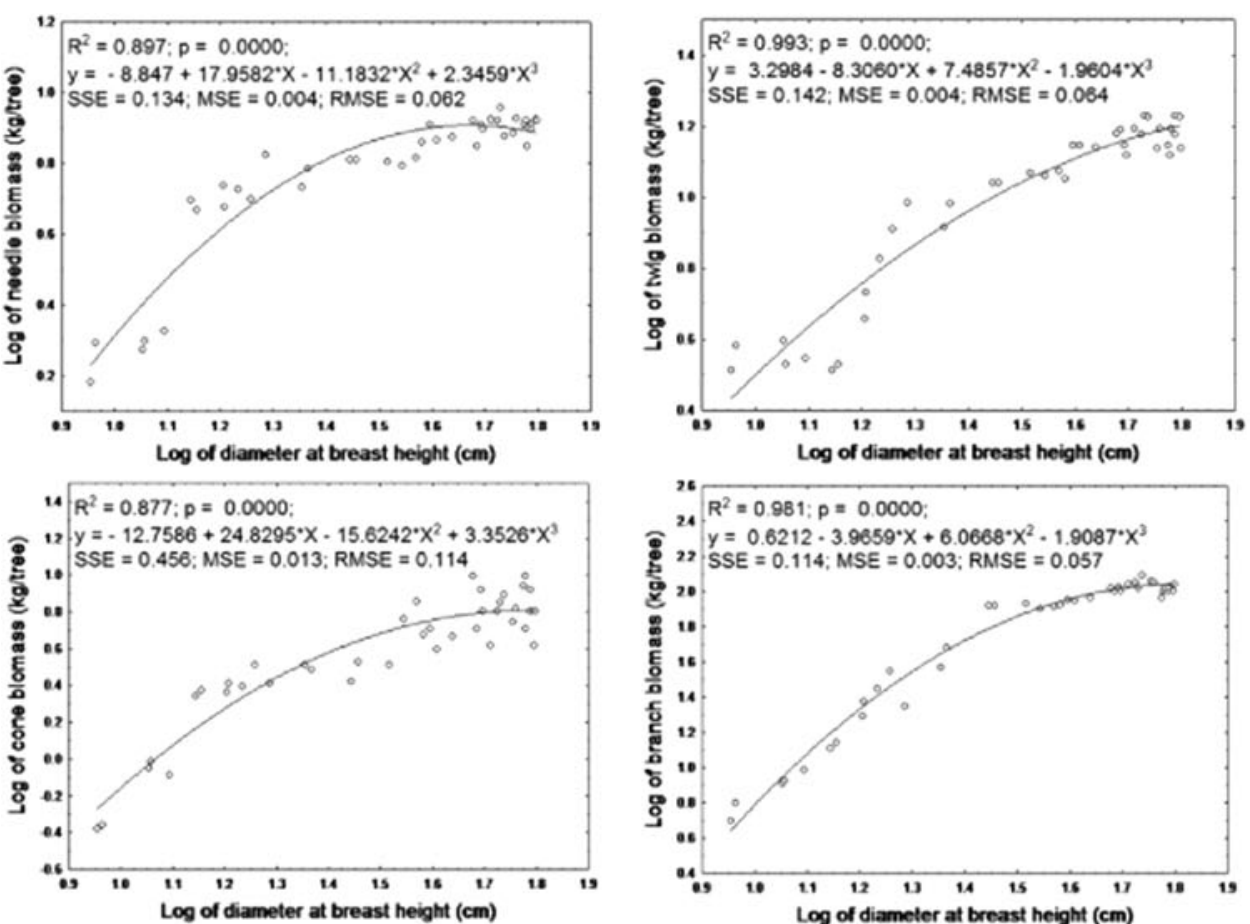

$24 R^{2}=0.981 ; p=0.0000 ;$

$24 y=0.6212 \cdot 3.9659^{\circ} X+6.0668 \cdot X^{2} \cdot 1.9087^{*} X^{3}$ $\$ 22, \begin{aligned} & y=0.6212 \cdot 3.96599^{\circ} \times+6.0668 \cdot x^{2} \cdot 1.9087 \\ & \text { SSE }=0.114 ; \text { MSE }=0.003 ; \text { RMSE }=0.057\end{aligned}$

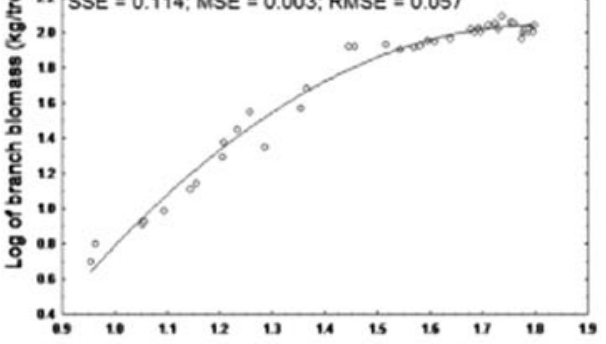

Log of diameter at breast height (cm)

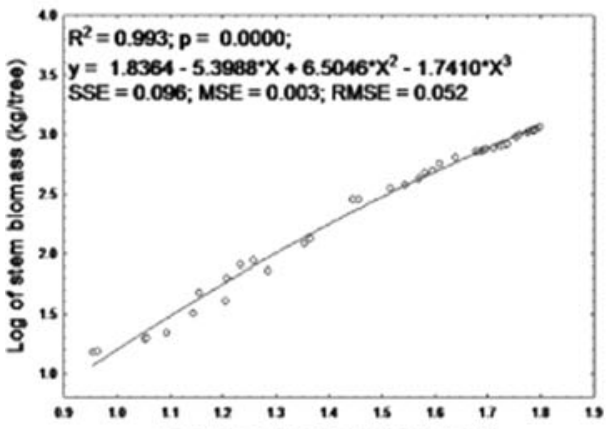

Log of diameter at breast height $(\mathrm{cm})$
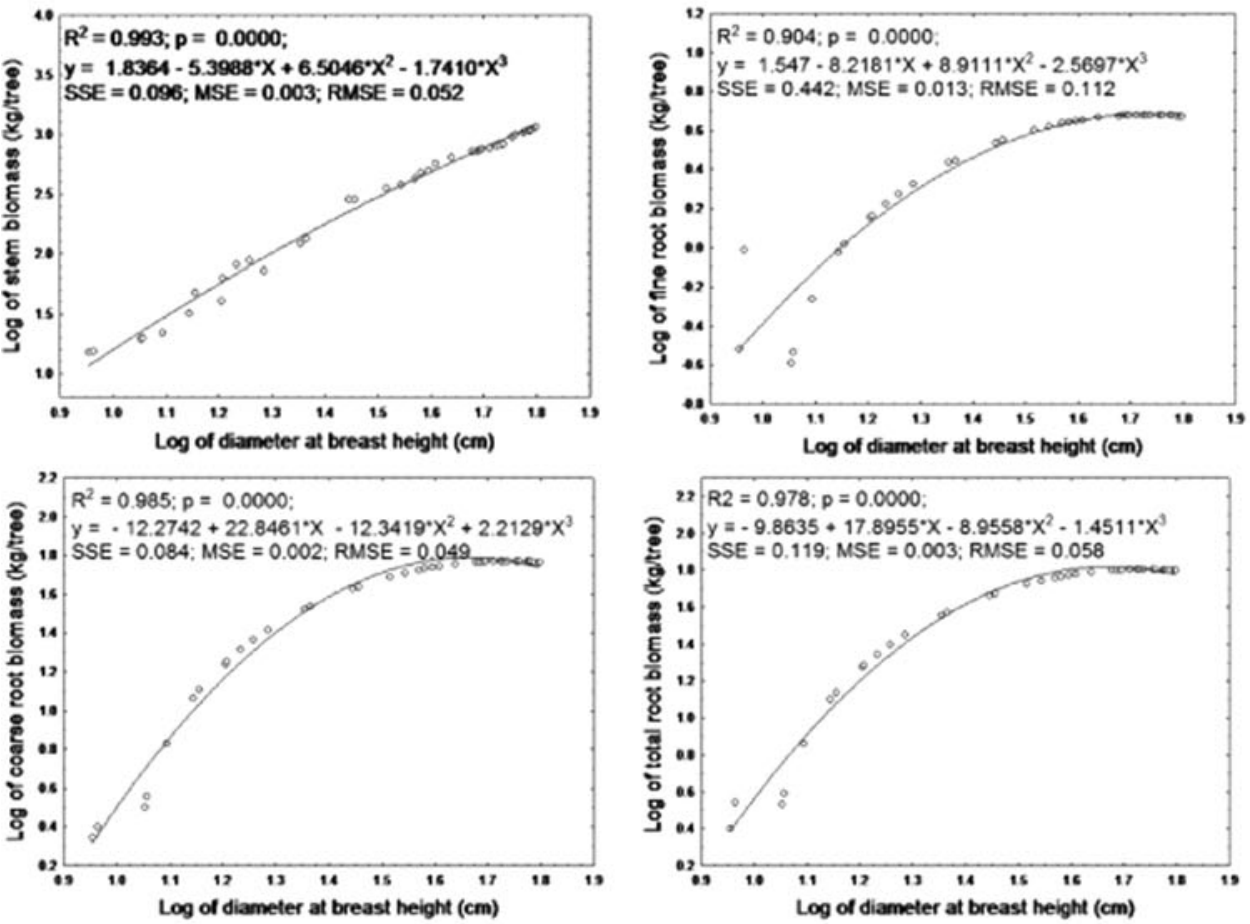

$22 R 2=0.978 ; p=0.0000 ;$

$20 y=-9.8635+17.8955^{\circ} x-8.9558^{\circ} x^{2}-1.4511^{\circ} x$

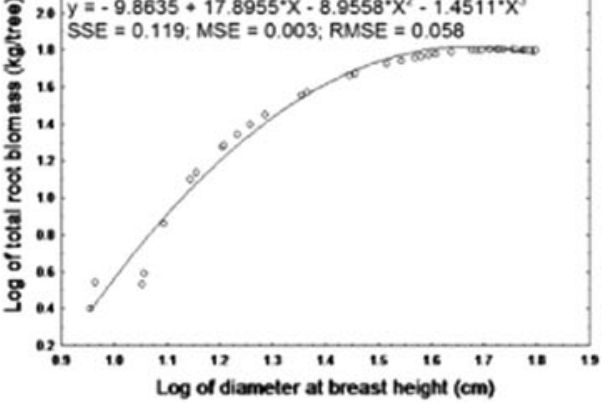

$34 R^{2}=0.993 ; p=0.0000$

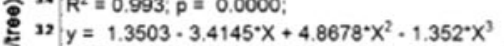

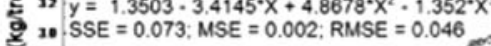

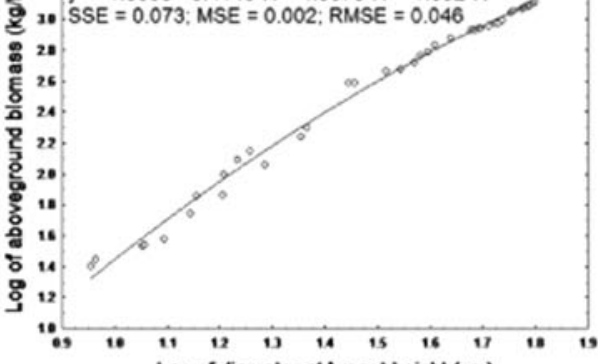

Log of diameter at breast height $(\mathrm{cm})$

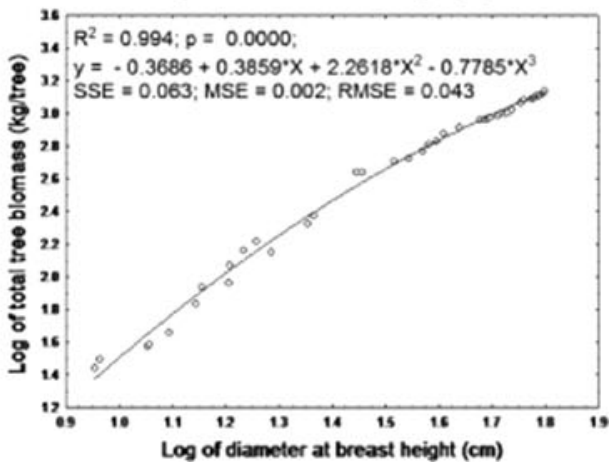


Table 2 Total ecosystem, above- and belowground biomass, carbon content and net primary production of an old-growth Pinus kesiya forest in north-eastern India

\begin{tabular}{|c|c|c|c|c|c|}
\hline Component & $\begin{array}{l}\text { Biomass } \\
\left(\mathrm{Mg} \mathrm{ha}^{-1}\right)\end{array}$ & $\begin{array}{l}\text { Carbon } \\
\left(\mathrm{Mg} \mathrm{C} \mathrm{ha}^{-1}\right)\end{array}$ & $\%$ contribution & $\begin{array}{l}\text { Net primary } \\
\text { production } \\
\left(\mathrm{Mg} \mathrm{ha}^{-1} \mathrm{yr}^{-1}\right)\end{array}$ & $\%$ contribution \\
\hline \multicolumn{6}{|l|}{ Aboveground biomass of Pinus kesiya } \\
\hline - Stem & $291.8 \pm 33.0$ & 143.0 & 63.4 & 9.8 & 56.0 \\
\hline - Branch & $48.2 \pm 2.0$ & 23.6 & 10.5 & 1.5 & 8.6 \\
\hline - Twig & $7.3 \pm 0.5$ & 3.6 & 1.6 & 0.7 & 4.0 \\
\hline - Needle & $4.3 \pm 0.4$ & 2.1 & 0.9 & 0.5 & 2.9 \\
\hline - Reproductive parts & $3.1 \pm 0.2$ & 1.5 & 0.7 & 0.3 & 1.7 \\
\hline $\begin{array}{l}\text { Aboveground biomass of } \\
\text { broad-leaved species }\end{array}$ & $62.2 \pm 40.3$ & 30.5 & 13.5 & 3.2 & 18.3 \\
\hline Herbs & $0.1 \pm 2.5$ & 0.1 & 0.03 & 0.0 & 0.0 \\
\hline Shrubs & $0.6 \pm 4.6$ & 0.3 & 0.12 & 0.0 & 0.0 \\
\hline \multicolumn{6}{|l|}{ Detrital biomass } \\
\hline - Needle & $1.0 \pm 1.6$ & 0.5 & 0.2 & 0.0 & 0.2 \\
\hline - Twig & $0.7 \pm 2.4$ & 0.3 & 0.2 & 0.0 & 0.1 \\
\hline - Branch & $0.1 \pm 1.4$ & 0.1 & 0.0 & 0.0 & 0.1 \\
\hline - Reproductive parts & $0.4 \pm 2.2$ & 0.2 & 0.1 & 0.0 & 0.2 \\
\hline - Total detrital biomass & $2.3 \pm 7.6$ & 1.1 & 0.5 & 0.1 & 0.5 \\
\hline Total aboveground biomass & 419.7 & 205.7 & 91.2 & 16.1 & 92.0 \\
\hline \multicolumn{6}{|l|}{ Belowground biomass of Pinus kesiya } \\
\hline - Fine roots $(<2 \mathrm{~mm})$ & $2.4 \pm 4.7$ & 1.1 & 0.5 & 0.3 & 1.7 \\
\hline - Coarse roots $(>2 \mathrm{~mm})$ & $29.4 \pm 7.2$ & 13.5 & 6.4 & 0.7 & 4.1 \\
\hline Belowground biomass of others species & $9.0 \pm 1.7$ & 4.1 & 1.9 & 0.4 & 2.2 \\
\hline - Total forest & 460.5 & 224.4 & 100.0 & & \\
\hline - Total soil organic carbon & & 58.7 & & & \\
\hline Total ecosystem & 460.5 & 283.1 & 100.0 & 17.5 & 100.0 \\
\hline BNPP & & & & 0.1 & 8.0 \\
\hline ANPP & & & & 0.9 & 92.0 \\
\hline
\end{tabular}

have argued that log-transformed nonlinear regression models produce up to $20 \%$ error for certain components if they are back-transformed into linear form. The back transformation is acceptable if MSE is not too large (Baskerville 1972). In this study, the MSE and RMSE values for different tree components are extremely low.

The AGB in this old-growth Pinus kesiya forest (419.7 $\mathrm{Mg} \mathrm{ha}^{-1}$ ) was about $36 \%$ greater than that of the 22-year-old young forest studied by Das and Ramakrishnan (1987) (308.7 Mg ha ${ }^{-1}$ ). Increase in AGB with age was also depicted through the studies conducted by Ovington and Madgwick (1959), and Delrio et al. (2008) for Pinus sylvestris L. for young- and old-growth forests respectively. A similar increase was also noted from the studies of Karizumi (1974) and Tanabe et al. (2003) for Pinus densiflora Sieb. et Zucc. The AGB obtained in this study is comparable with a 41-80-year-old $P$. sylvestris forest in Spain (359.7-456.9 $\mathrm{Mg} \mathrm{ha}^{-1}$ ) (Delrio et al. 2008). However, it is much greater than that of a 71-80-year-old Pinus koraiensis Sieb. et Zucc. forest of Japan (317.9 $\mathrm{Mg} \mathrm{ha}^{-1}$ ) (Son et al. 2001). The AGB obtained in the present study was also greater than that of most tropical forests studied. Muller (1982) obtained an AGB of $330 \mathrm{Mg} \mathrm{ha}^{-1}$ for the tropical broad-leaved forests of the eastern hardwood region of USA, and Brown et al. (1989) reported 238-341 Mg ha for Cameroon and 153-221 Mg ha ${ }^{-1}$ for Sri Lanka. However, the AGB of the present study is comparable with the findings of Brown et al. (1989) for the tropical rain forests of Malaysia (225-446 Mg ha' ${ }^{-1}$ ).

The $50-60 \mathrm{~cm}$ tree diameter class contributed $27.8 \%$ to the total tree $\mathrm{AGB}$, indicating the important role of this diameter class in carbon storage. The larger trees $(>60 \mathrm{~cm}$ DBH) contributed $15.8 \%$ to the total aboveground biomass. Thus, the large trees together accounted for more than $43 \%$ of the total carbon in the tree component. The greater contribution of large trees to AGB is in conformity with the findings of earlier workers (Baishya et al. 2009; Brown 1996; Brown and Lugo 1992), who had found that large 
Fig. 2 Diameter-density distribution of Pinus kesiya in an old-growth pine forest of north-eastern India. Bars show standard error

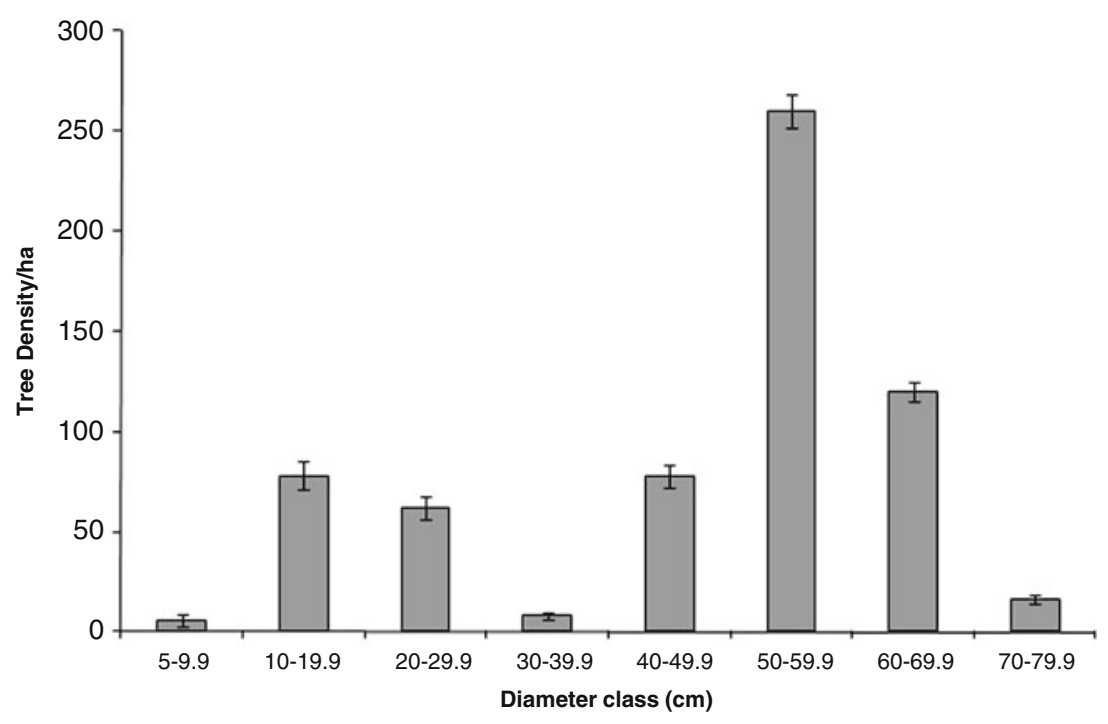

trees contributed up to $50 \%$ of the aboveground biomass. The smaller diameter trees thus had about $57 \%$ of the total tree carbon in this forest, indicating their importance in carbon storage.

The annual litterfall in this old-growth $P$. kesiya forest (2.3 $\mathrm{Mg} \mathrm{ha}^{-1}$ ) was greater than that in the 22-year-old forest (1.5 Mg ha ${ }^{-1}$ ) reported by Arunachalam et al. (1996). The amount of annual litter fall is within the reported range of 2.2-22.6 Mg ha ${ }^{-1}$ for various tropical and subtropical forests (Vogt et al. 1986). The proportion of leaf litter in the total litter was $42.6 \%$, and the twigs, branches, and reproductive parts accounted for $14.9 \%, 10.6 \%$, and $31.9 \%$ respectively. Arunachalam et al. (1996) reported that leaf litter constituted as high as $75 \%$ of the total litter in the young 22-year-old P. kesiya forest stand. Therefore, it is evident that with increasing age of a $P$. kesiya forest, the relative proportion of leaf litter in the litter decreases.

Fine and coarse root biomass of $P$. kesiya contributed 6\% and $72 \%$ to the total root biomass respectively. The fine root biomass was lower $\left(2.4 \mathrm{Mg} \mathrm{ha}^{-1}\right)$ than the values reported by Arunachalam et al. (1996) (3.4-5.1 $\left.\mathrm{Mg} \mathrm{ha}^{-1}\right)$ and by John et al. (2001) $\left(4.6 \mathrm{Mg} \mathrm{ha}^{-1}\right)$ in a 22-year-old and 23-year-old $P$. kesiya plantation forest, indicating the reduction of fine root production in old-growth forest. The fine root biomass obtained in the present study was also lower than the global range of $1.0-17.7 \mathrm{Mg} \mathrm{ha}^{-1}$ for various ecosystems (Vogt et al. 1986). Low availability of soil nutrients and water has been reported to promote high production and accumulation of fine roots (Vogt et al. 1986).

The BGB in this forest was $8.9 \%$ of the total tree biomass, which is within the range reported by earlier workers. Cairns et al. (1997) concluded that the BGB of an ecosystem can reach up to $25 \%$ of the total tree biomass. The contribution of shrub and herb components to the total forest biomass was negligible (0.15\%). Brown (1997) concluded that shrubs and herbs can contribute up to $3 \%$ of the total forest AGB.

The total NPP of the forest was high, which may be attributed to relatively higher soil NPK content and moisture regime in this pine forest. Gower et al. (1994) reported that $\mathrm{N}$ fertilization increases NPP of forest, and carbon allocation to belowground components decreases with increase in soil $\mathrm{N}$ availability (Haynes and Gower 1995). The extremely low BGB (40.8 $\mathrm{Mg} \mathrm{ha}^{-1}$ ) obtained in this study may be attributed to this reason. Vogt et al. (1996) reported that root NPP does not depend only on nutrient availability for many pine species. Relatively low root NPP as observed in this study $\left(1.4 \mathrm{Mg} \mathrm{ha}^{-1} \mathrm{yr}^{-1}\right)$ in comparison to other studies (Karizumi 1974) supports this argument.

The total aboveground NPP in this old-growth forest (16.1 $\mathrm{Mg} \mathrm{ha}^{-1} \mathrm{yr}^{-1}$ ) was lower than the younger (5-22year-old) $P$. kesiya forest (30.1-20.1 $\mathrm{Mg} \mathrm{ha}^{-1} \mathrm{yr}^{-1}$ ) reported by Das and Ramakrishnan (1987). The total aboveground NPP was higher than most pine forests around the world. For example, Chaturvedi and Singh $(1982,1987)$ and Rana et al. (1989) calculated the aboveground NPP for Pinus roxburghii forest $\left(6.1-15.6 \mathrm{Mg} \mathrm{ha}^{-1} \mathrm{yr}^{-1}\right)$ in the central Himalayas of India. Ma (1988) reported NPP of 3.5-17.5 Mg ha ${ }^{-1} \mathrm{yr}^{-1}$ for 33-70-year-old Pinus tabulaeformis forest from China. The high productivity of $P$. kesiya may be attributed to high net assimilation rate due to prolonged photosynthetic activity, and higher uptake of nutrients due to rapid turnover of nutrients (Das and Ramakrishnan 1987). The potential of a forest to sequester carbon depends on the forest type, age of forest and size class of trees (Terakunpisut et al. 2007). Considering the NPP level, tree diameter distribution, species composition and the age of the forest, it can be concluded that the forest is yet to fully mature and has the potential to store additional carbon in the future. 
Acknowledgements The first author is thankful to CSIR-UGC, Government of India, for financial assistance in the form of UGCNET (SRF) fellowship. The authors are thankful to the Forest Department, Government of Meghalaya for giving permission to conduct the study in the reserved forest. The support received from Dr. Krishna Upadhaya, Dr. Dibyendu Adhikari, Dr. Nigyal John Lakadong and Mr. Arun Chettri during the field study is gratefully acknowledged.

\section{References}

Anderson JM, Ingram JSI (1993) Tropical soil biology and fertility. A handbook of methods. C.A.B. International, Wallingford UK, $221 \mathrm{p}$

Arunachalam A, Maithani K, Pandey HN, Tripathi RS (1996) The impact of disturbance on detrital dynamics and soil microbial biomass of a Pinus kesiya forest in north-east India. For Ecol Manage 88:273-282

Baishya R, Barik SK, Upadhaya K (2009) Distribution pattern of aboveground biomass in natural and plantation forests of humid tropics in northeast India. Trop Ecol 50:295-304

Barik SK, Tripathi RS, Pandey HN, Rao P (1996) Tree regeneration in a subtropical humid forest: effect of cultural disturbance on seed production, dispersal and germination. J Appl Ecol 33:15511560

Baskerville G (1972) Use of logarithmic regression in the estimation of plant biomass. Can J For Res 2:49-53

Beauchamp JJ, Olson JS (1973) Corrections for the bias in regression estimates after logarithmic transformation. Ecology 54:14031407

Brown S (1996) Tropical forests and the global carbon cycle: Estimating state and change in biomass density. In: Apps M, Price D (eds) Forest Ecosystems. Forest Management and the Global Carbon Cycle. NATO ASI Series. Springer, Berlin, pp $135-144$

Brown S (1997) Estimating biomass and biomass change of tropical forests: a primer. FAO Forestry paper 134. Food and Agriculture Organization, Rome, $55 \mathrm{p}$

Brown S, Lugo AE (1992) Aboveground biomass estimates for tropical moist forests of the Brazilian Amazon. Interciencia 17:818

Brown S, Gillespie A, Lugo A (1989) Biomass estimation methods for tropical forests with applications to forest inventory data. For Sci 35:881-902

Cairns MAS, Brown S, Helmer EH, Baumgardner GA (1997) Root biomass allocation in the world's upland forest. Oecologia 111:1-11

Chambers JQ, dos Santos J, Ribeiro RJ, Higuchi N (2001) Tree damage, allometric relationships, and aboveground net primary production in central Amazon forest. For Ecol Manage 152:73-84

Champion HG, Seth SK (1968) Revised survey of forest types of India. Managers of publications. Govt. of India, New Delhi, p 404

Changala EM, Gibson GL (1984) Pinus oocarpa Schiede international provenance trial in Kenya at eight years. In: Barnes RD, Gibson GL (eds) Provenance and genetic improvement strategies in tropical forest trees. Mutate Zimbabwe, Commonwealth Forestry Institute, Oxford. Forest Research Centre, Harare, pp 191-200

Chaturvedi OP, Singh JS (1982) Total biomass and biomass production in $P$. roxburghii trees growing in all aged natural forest. Can J For Res 12:632-640

Chaturvedi OP, Singh JS (1987) The structure and function of pine forest in Central Himalaya. I. Dry matter dynamics. Ann Bot $60: 237-252$
Clark DA, Brown S, Kicklighter D, Chambers JQ, Thomlinson JR, Ni J (2001) Measuring net primary production in forests: concepts and field methods. Ecol Appl 11:356-370

Clark KL, Gholz HL, Castro M (2004) Carbon dynamics along a chronosequence of slash pine plantations in North Florida. Ecol Appl 14:1154-1171

Das AK, Ramakrishnan PS (1987) Aboveground biomass and nutrient contents in an age series of Khasi pine (Pinus kesiya). For Ecol Manage 18:61-72

Delrio M, Barbeito I, Bravo-Oviedo A, Calama R, Canellas I, Herrero C, Bravo F (2008) Carbon sequestration in Mediterranean pine forests. In: Bravo F, Jandl R, LeMay V, Gadow K (eds), Managing forest ecosystems: The challenge of climate change. Springer Science+Business Media, Dordrecht, pp 221-245

Desai AR, Bolstad PV, Cook B, Davis KJ, Carey EV (2005) Comparing net ecosystem exchange of carbon dioxide between an old-growth and mature forest in the upper Midwest. USA Agric For Meteorol 128:33-55

Gower ST, Gholz HL, Nakane K, Baldwin VC (1994) Production and carbon allocation patterns of pine forests. Ecol Bull 43:115-135

Haridasan K, Rao RR (1985-1987). Forest flora of Meghalaya. Vol. I and II. Bishen Singh Mahendra Pal Singh, Dehra Dun India, 937 p

Haynes BE, Gower ST (1995) Belowground carbon allocation in unfertilized and fertilized red pine plantations in northern Wisconsin. Tree Physiol 15:317-325

John B, Pandey HN, Tripathi RS (2001) Vertical distribution and seasonal changes of fine and coarse root mass in Pinus kesiya Royle Ex.Gordon forest of three different ages. Acta Oecol 22:293-300

Karizumi N (1974) The mechanism and function of tree root in the process of forest production. I. Method of investigation and estimation of the root biomass. Bull Gov For Exp Stn 259:1-99

Kira T, Shidei T (1967) Primary production and turnover of organic matter in different forest ecosystems of the Western Pacific. Jpn J Ecol 17:70-87

Knohl A, Schulze ED, Kolle O, Buchmann N (2003) Large carbon uptake by an unmanaged 250-year-old deciduous forest in Central Germany. Agric For Meteorol 118:151-167

Kurz WA, Apps MJ (1995) An analysis of future carbon budgets of Canadian boreal forests. Water Air Soil Pollut 82:321-331

Law BE, Sun OJ, Campbell JL, Van Tuyl S, Thornton E (2003) Changes in carbon storage and fluxes in a chronosequence of ponderosa pine. Glob Chang Biol 9:510-524

Li R, Weiskittel AR (2010) Comparison of model forms for estimating stem taper and volume in the primary conifer species of the North American Acadian Region. Ann For Sci 67:302-316

Luo TX, Li WH, Zhu HZ (2002) Estimated biomass and productivity of natural vegetation on the Tibetan Plateau. Ecol Appl 12:980997

Ma QY (1988) A study on biomass and primary productivity of Chinese Pine (Pinus tabulaeformis Carr.). Ph.D. thesis. Beijing Forestry University, Beijing, $96 \mathrm{p}$

Malhi Y, Baldocchi DD, Jarvis PG (1999) The carbon balance of tropical, temperate and boreal forests. Plant Cell Environ 22:715-740

Melillo JM, McGurie AD, Kicklighter DW, Moore BIII, Vorosmarty CJ, Schloss AL (1993) Global climate change and terrestrial net primary production. Nature 263:234-240

Misra R (1968) Ecology workbook. Oxford \& IBH Publishing Co, Calcutta, India, $244 \mathrm{p}$

Muller RN (1982) Vegetation pattern in the mixed mesophytic forest of eastern Kentucky. Ecology 63:1901-1917

Ovington JD, Madgwick HAI (1959) Distribution of organic matter and plant nutrients in a plantation of Scots pine. For Sci 5:344-355

Ovington JD, Olson JS (1970) Biomass and chemical content of El Verde lower montane rain forest plants. In: Odum HT, Pigeon RF (eds) A tropical rainforest. US Atomic Energy Commission, 
National Technical Information Services. US Department of Commerce, Springfield, pp 35-61

Persson H (1978) Root dynamics in a young Scots Pine stand in Central Sweden. Oikos 30:508-519

Rana BS, Singh SP, Singh RP (1989) Biomass and net primary productivity in Central Himalayan forest along an altitudinal gradient. For Ecol Manage 27:199-218

Ravindranath NH, Somashekhar BS, Gadgil M (1997) Carbon flow in Indian forests. Clim Change 35:297-320

Richter DD, Markewitz D, Dunsomb JK, Wells CG, Stuanes A, Allen HL, Urrego B, Harrison K, Bonani G (1995) Carbon cycling sink and for the concept of soil. In: Mcfee WW, Kelly JM (eds) Carbon forms and functions in forest soils. Soil Science Society of America, Madison, WI, pp 233-251

Schmidt A, Poulain M, Klein D, Krause K, Peña-Rojas K, Schmidt H, Schulte A (2009) Allometric above-belowground biomass equations for Nothofagus pumilio (Poepp. \& Endl.) natural regeneration in the Chilean Patagonia. Ann For Sci 66:513-518

Schroeder P, Brown S, Mo J, Birdsey R, Cieszewski C (1997) Biomass estimation for temperate broadleaf forests of the United States using inventory data. For Sci 43:424-434
Son Y, Hwang JW, Kim ZS, Lee WK, Kim JS (2001) Allometry and biomass of Korean pine (Pinus koraiensis) in central Korea. Biores Technol 78:215-255

Tanabe H, Nakano T, Mimura M, Abe Y, Mariko S (2003) Biomass and net primary production of a Pinus densiflora forest established on a lava flow of Mt. Fuji in central Japan. J For Res 8:247-252

Terakunpisut J, Gajaseni N, Ruankawe N (2007) Carbon sequestration potential in aboveground biomass of Thong Pha Phun national forest. Thailand. Appl Ecol Environ Res 5:93-102

Ter-Mikaelian MT, Korzukhin MD (1997) Biomass equations for sixty five North American tree species. For Ecol Manage 97:1-24

Valentini R, Matteucci G, Dolman AJ et al (2000) Respiration as the main determinant of carbon balance in European forests. Nature 404:861-865

Vogt KA, Grier GC, Vogt DJ (1986) Production, turnover and nutrient dynamics of above- and below-ground detritus of world forests. Adv Ecol Res 15:303-377

Vogt KA, Vogt DJ, Palmiotto PA, Boon P, O'Hara J, Asbjornsen H (1996) Review of root dynamics in forest ecosystems grouped by climate, climatic forest type and species. Plant Soil 187:159-219 